\title{
PENGARUH GOOD CORPORATE GOVERNANCE, FIRM SIZE, STRUKTUR MODAL TERHADAP KINERJA KEUANGAN PADA PERUSAHAAN ANEKA INDUSTRI, INDUSTRI DASAR DAN KIMIA DI BEI PERIODE 2014-2017
}

\author{
Reizkey Napitupulu, Kristina, Rismawati Ndruru, Yanuari Waruwu, Tetty Tiurma Uli Sipahutar* \\ Universitas Prima Indonesia \\ *e-mail: reizkeynapitupulu1998@gmail.com
}

\begin{abstract}
DiPublikasi: 01/01/2021
http://dx.doi.org/10.22225/kr.11.2.1154.190-196

Abstract

This research is discussed to assess Good Corporate Governance (GCG) of Company Size, Capital Structure of Return on Investment in Various Industrial, Basic and Chemical Companies. Sampling using purposive sampling produced as many as 38 sample companies from a population of 110 companies with a total of 168 observations of the analysis unit. The results of the study stated that Good Corporate Governance (GCG), Company Size, and capital structure simultaneously had a significant and significant effect on return on investment (ROI) in various industries, basic industries, and chemicals on the Indonesia Stock Exchange. partially Good corporate governance has no effect and no significant effect on investment returns, company size partially has a negative and insignificant effect on investment returns and capital structure partially has a negative and significant effect on investment returns in companies in various industries, basic industries, and chemicals on the Indonesia Stock Exchange.

Keywords: Good Corporate Governance, Firm Size, Capital Structure, Return On Investment

Abstrak

Pengajian ini dibahas untuk menilai Good Corporate Governance (GCG) dari Ukuran Perusahaan, Struktur Modal atas Pengembalian Investasi di Berbagai Perusahaan Industri, Dasar dan Kimia. Pengambilan sampel menggunakan purposive sampling yang dihasilkan sebanyak 38 perusahaan sampel dari populasi 110 perusahaan dengan total 168 pengamatan unit analisis. Hasil penelitian menyatakan bahwa Good Corporate Governance (GCG), Ukuran Perusahaan, dan struktur modal secara simultan memiliki pengaruh yang signifikan dan signifikan terhadap pengembalian investasi (ROI) di berbagai industri, industri dasar, dan bahan kimia di Bursa Efek Indonesia. secara parsial Tata kelola perusahaan yang baik tidak berpengaruh dan tidak berpengaruh signifikan terhadap pengembalian investasi, ukuran perusahaan secara parsial memiliki pengaruh negatif dan tidak signifikan terhadap pengembalian investasi dan struktur modal secara parsial berpengaruh negatif dan signifikan terhadap pengembalian investasi di perusahaan di berbagai industri, industri dasar, dan bahan kimia di Bursa Efek Indonesia.
\end{abstract}

Kata Kunci : Good Corporate Governance, Firm Size, Struktur Modal, Return On Investment

\section{PENDAHULUAN}

Perusahaan adalah media yang digunakan dalam memperoleh laba maksimum untuk pemilik. Ketika ekonomi membaik, kepentingan perusahaan tidak hanya untuk pemilik tetapi juga penting bagi pihak lain seperti investor, calon investor, kreditor, dan bahkan bagi orang-orang yang memiliki minat pada perusahaan.

Perusahaan manufaktur di berbagai sektor industri dasar dan kimia adalah cara atau kegiatan untuk mengolah bahan mentah atau barang setengah jadi menjadi barang jadi yang memiliki nilai tambah untuk mendapat untung.

Berbagai produk industri dasar dan kimia seperti keramik, kemasan plastik, ban, cat, dan tekstil telah menembus pasar internasional dan berperan dalam pendapatan devisa negara. Industri ini diharapkan untuk selalu melakukan peningkatan kapasitas pasar atau penguasaan teknologi yang lebih efektif.

Dengan kata lain, kinerja keuangan perusahaan juga disebut sebagai pasak dan 
memperkirakan kinerja yang dapat dilihat dari situasi keuangan dalam periode tertentu. Situasi keuangan dapat dianalisis dengan menggunakan analisis keuangan.

Penerapan Tata Kelola Perusahaan yang Baik adalah cara yang sangat diperlukan untuk melepaskan diri dari ketegangan ekonomi yang melanda Indonesia. Fungsi dan tujuan kreditor asing dan investor mengenai penerapan prinsip-prinsip tata kelola perusahaan yang baik adalah aspek membuat kesimpulan berinvestasi di perusahaan.

Ukuran perusahaan (ukuran primer) mencerminkan bahwa perusahaan yang pasti dan besar akan memiliki saluran yang lebih halus ke pasar modal, dibandingkan dengan perusahaan kecil. Perusahaan baru memiliki keterbatasan atau akses ke pasar modal sehingga keahlian untuk mendapatkan modal dan mendapatkan pinjaman dari pasar modal juga pasti, karena itulah mengapa ukuran perusahaan dijadikan alasan investor menanamkan modalnya dengan menghitung ukuran perusahaan.

Masalah yang sering dihadapi oleh para pelaku bisnis atau setiap perusahaan yang bergerak di berbagai bisnis tidak dapat dipisahkan dari kepentingan dana untuk memanfaatkan bisnis mereka. Dalam struktur modal, ada kebijakan mengenai kaitan antara risiko dan tingkat pengembalian yang diinginkan semakin banyak, memicu utang tinggi. Tetapi meningkatkan laba yang diinginkan untuk semua perusahaan tidak lagi sama dengan kriteria penerimaan.

\section{TINJAUAN PUSTAKA}

\section{Kinerja keuangan}

Rasio dalam analisis laporan keuangan adalah nilai yang menunjukkan ikatan satu elemen dan elemen lainnya dalam laporan keuangan. Ikatan komponen-komponen laporan keuangan berikut dalam karakter matematika muda dari rasio individu berarti sedikit, kecuali bila dibedakan dari rasio standar yang cukup untuk membentuk dasar perbandingan (Jumingan, 2014). Faktor lain yang terkait dengan kinerja keuangan perusahaan yaitu keputusan tentang sumber pendanaan yang akan digunakan oleh perusahaan. Pemilihan sumber pendanaan menjadi pertimbangan yang matang dengan membandingkan kekurangan dan kelebihan dari masing masing alternatif pendanaan yang tersedia. Pendanaan internal dari dalam perusahaan sendiri atau eksternal berupa hutang (Sartono, 2010). Rumus dalam menghitung kinerja keuangan adalah sebagai berikut:

$$
R O I=\frac{\text { Laba bersih }(\text { setelah pajak }}{\text { Total aktiva }}
$$

\section{Tata Kelola Perusaaan yang Baik dalam Kinerja Keuangan}

Saat ini, ketentuan yang jelas dan tegas bahwa perusahaan yang ingin go public adalah perusahaan harus memiliki rencana dan menerapkan prinsip-prinsip ketentuan Tata Kelola Perusahaan Yang Baik (GCG) sehingga menjadi jelas kapan memeriksa beberapa perusahaan yang dianggap bermasalah di pasar modal (pasar modal) karena kinerja perusahaan yang mengalami masalah. Salah satu penyebab kinerja rendah adalah karena tidak jelas menerapkan prinsip-prinsip GCG (Fahmi, 2015). Proporsi dewan komisaris yang berasal dari luar perusahan atau komisaris independen juga mempengaruhi kinerja perusahaan yang bertindak sebagai penegah dalam perselisihan yang terjadi diantara para menejer internal dan mengawasi kebijakan manajemen serta memberikan nasihat kepada menejemen. Komisaris independen merupakan posisi terbaik untuk melaksanakan fungsi monitoring agar tercipta perusahaan yang Good Corporate Governance (Veno, 2015).

$$
\text { proporsi komisari's independen }=\frac{\text { jumlah anggota komisarisis independen }}{\text { jumlah seluruh anggota dewan komisaris }}
$$

\section{Pengaruh Ukuran Perusahaan pada Kinerja Keuangan}

Ukuran perusahaan merupakan hal yang penting dalam proses pelaporan keuangan. Ukuran perusahaan dalam penelitian ini diukur dengan melihat seberapa besar aset yang dimiliki oleh sebuah perusahaan. Aset yang dimiliki perusahaan 
ini menggambarkan hak dan kewajiban serta permodalan perusahaan. Perusahaan dengan aset besar biasanya akan mendapatkan perhatian lebih dari masyarakat. Perusahaan diharapkan akan selalu berusaha akan menjaga stabilitas kinerja keuangan mereka.pelaporan kondisi keuangan yang baik ini tentu tidak serta merta dapat dilakukan tanpa melalui kinerja yang baik dari semua dari semua lini perusahaan (Panky Pradana Sukandar, 2014). Salah satu tolak ukur yang menunjukkan besar kecilnya perusahaan adalah ukuran perusahaan. Faktor ukuran perusaan yang menentukan besar kecilnya perusahaan merupakan faktor penting dalam menentukan laba. Perusaaan yang besar dianggap telah mencapai tahap kedewasaan suatu gambaran bahwa perusahaan tersebut relatif lebih stabil dan lebih mampu menghasilkan laba dibandingkan perusahaan kecil (Sembiring, 2008).

\section{ukuran perusahaan: $\mathrm{Ln}$ (total asset)}

\section{Pengaruh Struktur Modal terhadap Kinerja}

\section{Keuangan}

struktur modal adalah proporsi dalam

menentukan pemenuhan kebutuhan belanja perusahaan dimana dana yang diperoleh menggunakan kombinasi atau paduan sumber yang berasal dari dana jangka panjang yang terdiri dari dua sumber utama yakni yang berasal dari dalam dan luar perusahaan (Rodoni, Ahmad dan Ali, 2010). Keputusan struktur modal yang efektif dapat merendahkan biaya modal yang dikeluarkan oleh perusahaan, sebaliknya jika struktur modal yang buruk akan berpengaruh pada besarnya biaya modal perusahaan yang akan dikeluarkan. Besarnya biaya modal yang dikeluarkan perusahaan juga akan memberikan dampak pada kinerja sebuah perusahaan (Nugraha, 2013).

\section{DER $=\frac{\text { TOTAL HUTANG }}{\text { TOTAL MODAL }}$}

\section{METODE PENELITIAN}

Pendekatan yang dibuat dalam penelitian ini ialah pendekatan kuantitatif. Menurut (Sugiyono., 2016), "metode penelitian kuantitatif bisa dikatakan seperti yang dilandaskan pada filsafat positivisme, dipakai selama meneliti populasi atau sampel terpilih, pengumpulan data memakai instrumen penelitian, pemeriksaan data bersifat kuantitatif/statistik, bertujuan untuk menilai hipotesis yang sudah disepakati". Menurut (Sugiyono., 2016), "Sampel merupakan bagian dari hasil dan karakter yang dimiliki oleh populasi tersebut". Teknik pengambilan sampel menggunakan purposive sampling. Menurut (Sugiyono., 2016), teknik purposive sampling adalah teknik penentuan sampel tertentu.

Dalam penelitian ini, kriteria yang ditetapkan adalah sebagai berikut :

1. Perusahaan aneka industri, industri dasar dan kimia yang terdaftar di Bursa efek Indonesia

2. Perusahaan aneka industri, industri dasar dan kimia yang mempublikasikan laporan keuangan lengkap secara berturut-turut dari tahun 2014-2017.

3. Perusahaan aneka industri, industri dasar dan kimia yang mengalami keuntungan dari tahun 2014-2017.

Hipotesis diuji dengan analisis regresi berganda untuk menganalisis pengaruh variabel independen terhadap variabel dependen. Model regresi yang digunakan yaitu :

$$
\mathrm{Y}=\mathrm{a}+\mathrm{b}_{1} \mathrm{X}_{1}+\mathrm{b}_{2} \mathrm{X}_{2}+\mathrm{b}_{3} \mathrm{X}_{3}+\mathrm{e}
$$

Keterangan :

$$
\begin{array}{ll}
\mathrm{Y} & =\text { Kinerja Keuangan } \\
\mathrm{a} & =\text { Konstanta } \\
\mathrm{X}_{1} & =\text { Good Corporate Governance } \\
\mathrm{X}_{2} & =\text { Firm Size } \\
\mathrm{X}_{3} & =\text { Struktur Modal } \\
\mathrm{b}_{1}, \mathrm{~b}_{2}, \mathrm{~b}_{3} & =\text { Koefisien regresi } \\
\mathrm{e} & =\text { Variabel pengganggu }
\end{array}
$$

\section{HASIL DAN PEMBAHASAN}

Data dalam penelitian ini berasal dari perusahaan Manufaktur sektor aneka industri,industri dasar dan kimia yang terdaftar di Bursa Efek Indonesia dari tahun 2014-2017. Sebagai objek dan penelitian sebagai objek dan 
penelitian sesudah dilakukan penelitian berdasarkan kriteria yang ditetapkan, sehingga didapat 38 perusahaan menjadi sampel penelitian dalam 4 tahun penelitian.

\section{Tabel 1}

Uji Normalitas

\begin{tabular}{llllll}
\hline & $\mathrm{N}$ & $\begin{array}{l}\text { Minimu } \\
\mathrm{m}\end{array}$ & $\begin{array}{l}\text { Maximu } \\
\mathrm{m}\end{array}$ & Mean & Std. \\
& & & & & Deviation \\
\hline $\begin{array}{l}\text { LN_GCG } \\
\text { LN_FRIMSIZE }\end{array}$ & 152 & -1.95 & -.18 & - & .35255 \\
& 152 & 2.67 & 3.37 & 1.0033 & .23687 \\
$\begin{array}{l}\text { LN_STRUKTU } \\
\text { RMO }\end{array}$ & 152 & -6.75 & 1.64 & -.5148 & 1.09242 \\
$\begin{array}{l}\text { DAL } \\
\text { LN_ROI }\end{array}$ & 152 & -7.77 & .60 & - & 1.47054 \\
$\begin{array}{l}\text { Valid N } \\
\text { (listwise) }\end{array}$ & 152 & & & 3.3316 & \\
\hline
\end{tabular}

Hasil Output SPSS,2020

Berdasarkan hasil uji statistik deskriptif pada tabel 1 bisa kita ketahui bahwa:

1. Variabel Good corporate governance (GCG) mempunyai hasil minimum sebesar -1.95.

hasil maksimum sebesar -.18 dengan hasil rata rata sebesar 1.0033 dan hasil standar deviasi sebesar 0,35255.

2. Variabel firm size mempunyai hasil minimum sebesar 2,67, hasil maksimum sebesar 3,37, dengan hasil rata-rata sebesar 3,0810 dan hasil standar deviasi sebesar 0,23687 .

3. Variabel struktur modal mempunyai hasil minimum sebesar -6.75, hasil maksimum sebesar 1,64, dengan hasil rata rata sebesar -5148 dan hasil standar deviasi sebesar 1,09242.

4. Variabel kinerja keuangan (Roi) mempunyai hasil minimum sebesar -7,77, hasil maksimum sebesar 0,60 , hasil rata-rata sebesar $-3,3316$ dan hasil standar deviasi 1,47 .

\section{Gambar 1}

Hasil uji Normalitas Histogram

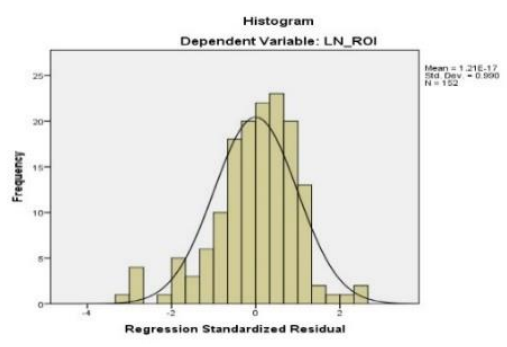

Hasil uji grafik histogram terlihat pada gambar 1 menyatakan bahwa garis kurva cenderung simetri. Gambar ini memperlihatkan jika data berdisttribusi normal dan mencukupi asumsi normalitas.

Tabel 2

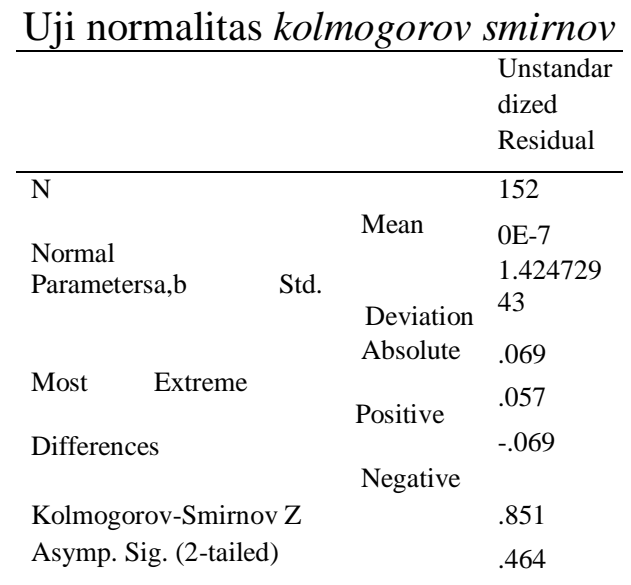

\section{Hasil Output SPSS,2020}

Hasil uji normalitas kolmogorov smirnov menyatakan hasil signifikan 0,464 >0,05 karena itu hasil uji normalitas kolmogrov smirnov dapat disimpulkan data berdistribusi normal. 
Tabel 3

Uji Multikolonieritas

\begin{tabular}{|c|c|c|c|c|c|c|c|c|}
\hline \multirow{2}{*}{\multicolumn{2}{|c|}{ Model }} & \multicolumn{2}{|c|}{$\begin{array}{l}\text { Unstandardize } \\
\text { d Coefficients }\end{array}$} & \multirow{2}{*}{$\begin{array}{l}\text { Standardized } \\
\text { Coefficients } \\
\text { Beta }\end{array}$} & \multirow[t]{2}{*}{$\mathrm{T}$} & \multirow[t]{2}{*}{ Sig. } & \multicolumn{2}{|c|}{$\begin{array}{l}\text { Collinearity } \\
\text { Statistics }\end{array}$} \\
\hline & & B & $\begin{array}{l}\text { Std. } \\
\text { Error }\end{array}$ & & & & $\begin{array}{l}\text { Toler } \\
\text { ance }\end{array}$ & VIF \\
\hline \multirow{7}{*}{1} & (Constant) & - & 1.652 & & & .07 & & \\
\hline & & 3.011 & & & 1.823 & 0 & & \\
\hline & LN_GCG & .089 & .336 & .021 & .266 & .79 & .976 & 1.025 \\
\hline & LN_FRIM & & & & -.257 & 1 & & \\
\hline & SIZE & -.131 & .510 & -.021 & & .79 & .939 & 1.065 \\
\hline & LN_STRU & & & & 3.081 & 80 & & \\
\hline & $\begin{array}{l}\text { KTURM } \\
\text { ODAL }\end{array}$ & -.337 & .109 & -.250 & & 2 & .962 & 1.040 \\
\hline
\end{tabular}

Hasil Output SPSS,2020

Berdasarkan hasil pengelolahan data pada tabel 3, besarnya nilai Tolerance variabel GCG, Frim Size dan Struktur Modal berada diatas 0,10 sedangkan angka VIF variabel Good Corporate Governance (GCG), frim Size dan Struktur Modal berada dibawah 10. Dengan begitu nilai uji miltikolinearitas setelah transformasi tidak ada regresi antar variabel independen.

\section{Tabel 4}

Uji Autokolerasi

\begin{tabular}{llllll}
\hline Model & $\mathrm{R}$ & $\mathrm{R}$ & $\begin{array}{l}\text { Adjusted R Std. Error } \\
\text { Square }\end{array}$ & $\begin{array}{l}\text { Durbin- } \\
\text { Square } \\
\text { of the } \\
\text { Estimate }\end{array}$ & \\
\hline 1 & $.248^{\mathrm{a}}$ & .061 & .042 & 1.43910 & 2.069 \\
\hline
\end{tabular}

Hasil Output SPSS, 2020

Hasil uji Durbin-Watson menyatakan angka 2,069, sedangkan tabel DW buat "K" = 3 (jumlah variabel bebas) dan $\mathrm{n}=38$ (jumlah data) besar nilai dl (batas bawah) $=1.318$ dan du (batas atas) $=1.656 ; 4-\mathrm{dl}=$ 2,682 dan $4-d u=2,344$. Dengan memeriksa kriteria pada arahan Durbin- Watson maka hasil $\mathrm{du}<\mathrm{dw}<4$ du atau 1,656 <2,069 < 2,344. jadi nilai autokolerasi menunjukkan tidak terdapat autokorelasi positif dan negatif.

\section{Gambar 2}

Uji Heteroskedastisitas

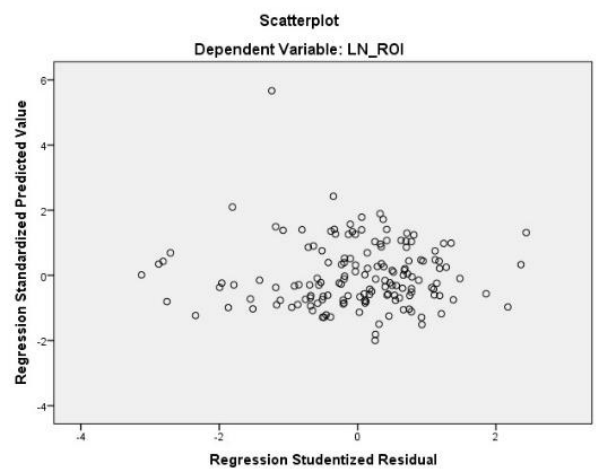

Hasil Output SPSS,2020

Pada gambar 2. Terdapat pada titik-titik diatas memencar secara merambang diatas atau dibawah angka 0 (nol) pada sumbu Y tidak tergabung disatu letak jadi dari grafik scatterplot dapat diartikan bahwa tidak timbul heteroskedastisitas pada model rogresi. 


\begin{tabular}{|c|c|c|c|c|c|c|}
\hline \multicolumn{7}{|c|}{$\begin{array}{c}\text { Tabel } 5 \\
\text { Uji Gletser }\end{array}$} \\
\hline & \multirow[t]{2}{*}{ Model } & \multicolumn{2}{|c|}{$\begin{array}{l}\text { Unstandardized } \\
\text { Coefficients }\end{array}$} & \multirow{2}{*}{$\begin{array}{c}\text { Standardiz } \\
\text { ed } \\
\text { Coefficien } \\
\text { ts } \\
\text { Beta }\end{array}$} & \multirow[t]{2}{*}{$\mathrm{t}$} & \multirow[t]{2}{*}{ Sig. } \\
\hline \multirow{5}{*}{1} & & & & & & \\
\hline & (Constant) & -3.011 & 1.652 & & -1.823 & .791 \\
\hline & LN_GCG & .089 & .336 & .021 & .266 & .797 \\
\hline & LN_FRIMSIZE & -.131 & .510 & -.021 & -.257 & .002 \\
\hline & $\begin{array}{l}\text { LN_STRUKTU } \\
\text { RMODAL }\end{array}$ & -.337 & .109 & -.250 & -3.081 & .002 \\
\hline
\end{tabular}

Hasil Output SPSS,2020

Nilai uji Gletser atas tabel 5. Menyatakan hasil signifikan dari ketiga variabel independen GCG, Frim Size, dan Struktur modal diatas dari 0,05 . sebab itu kesimpulan uji Gletser tidak timbul masalah heteroskedastisitas pada observasi ini.

\section{Tabel 6}

Analisis Data Berganda

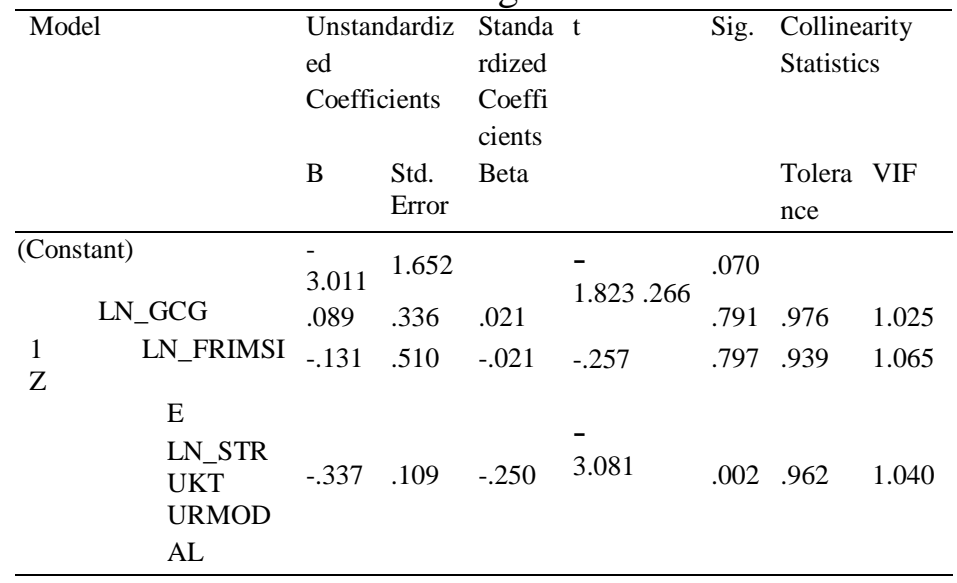

\section{Hasil Output SPSS,2020}

Berdasarkan tabel 6 diatas menghasilkan rumus regresi tersebut :ROI $=-3.011+$ 0,089 GCG -131 Frim size -337 Struktur modal nilai intrepretasi dari regresi diatas ialah:

1. Hasil A sebesar -3.011 maksudnya bila variabel Good Corporate Governance, Frim Size, Struktur Modal, Return On Investment (ROI) adalah senilai -3.11

2. Hasil koefisien Good Corporate Governance 0,089. Ini menyatakan bahwa setiap penurunan GCG satu kali maka kinerja keuangan (Return
On Investment) akan merasakan kenaikan sebesar 0,089

3. hasil koefisien Frim Size (X2) senilai -0,131. Ini menyatakan setiap penurunan Frim Size satu kali maka Kinerja Keuangan (ROI) mengalami kenailan senilai -0,131.

4. hasil koefisien Struktur Modal sebesar -0,337.mengatakan semua kenaikan Struktur Modal sekali jadi Kinerja Keuangan (ROI) akan mengalami kenaikan senilai -0,337. 
Tabel 7

Uji Koefisien Determinasi

\begin{tabular}{lllll}
\hline Model & $\mathrm{R}$ & R Square & $\begin{array}{l}\text { Adjusted } \\
\text { Square }\end{array}$ & $\begin{array}{c}\mathrm{R} \\
\begin{array}{l}\text { Std. Error of } \\
\text { the Estimate }\end{array}\end{array}$ \\
\hline 1 & $.248^{\mathrm{a}}$ & .061 & .042 & 1.43910
\end{tabular}

Square $\left(\mathrm{R}^{2}\right)$ koefisien determinasi senilai 0,042 serupa dengan $4,2 \%$ variabel independen dipengaruhi oleh kinerja keuangan (ROI) senilai $4,2 \%$ dan sisahnya senilai $95,8 \%$ dipengaruhi oleh variabel lainnya.

Hasil Outpus SPSS,2020

Berdasarkan tabel 7 berikut hasil adjusted

\section{Tabel 8}

Uji Hipotesis

Secara Simultan (F)

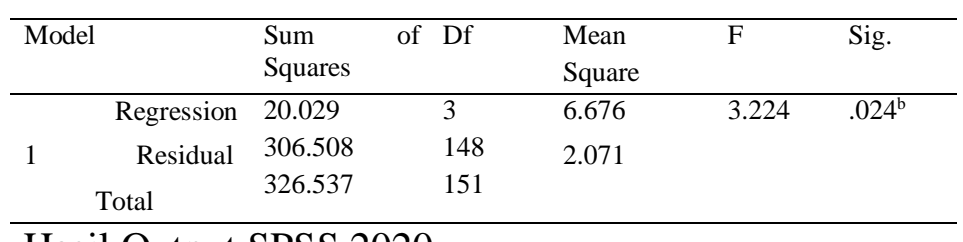

Hasil Output SPSS,2020

Berdasarkan tabel 8 berikut, nilai $F_{\text {hitung }}$ ialah senilai 3,224 dengan hasil signifikan 0,024 sementara $F_{\text {tabel }}$ adalah senilai 2,66 bisa disimpulkan $F_{\text {hitung }}>F_{\text {tabel }}(3,224>2,66)$ dengan hasil signifikan 0,024 diatas 0,05 jadi $\mathrm{H}_{0}$ diterima maksudnya secara serentak $G C G$, Frim size, dan Struktur modal tidak berpengaruh terhadap ROI pada perusahaan yang diteliti.

\section{Tabel 9}

\begin{tabular}{|c|c|c|c|c|c|c|}
\hline \multirow[t]{2}{*}{$\begin{array}{l}\text { Mode } \\
1\end{array}$} & & \multicolumn{2}{|c|}{$\begin{array}{l}\text { Unstandardized } \\
\text { Coefficients }\end{array}$} & \multirow{2}{*}{$\begin{array}{l}\text { Standardize } \\
\text { d } \\
\text { Coefficients } \\
\text { Beta }\end{array}$} & \multirow[t]{2}{*}{$\mathrm{T}$} & \multirow[t]{2}{*}{ Sig. } \\
\hline & & B & $\begin{array}{l}\text { Std. } \\
\text { Error }\end{array}$ & & & \\
\hline \multirow{4}{*}{1} & (Constant) & -3.011 & 1.652 & & -1.823 & .070 \\
\hline & ln_gcg & .089 & .336 & .021 & .266 & .791 \\
\hline & ln_frimsize & -.131 & .510 & -.021 & -.257 & .797 \\
\hline & $\begin{array}{l}\text { ln_strukturm } \\
\text { odal }\end{array}$ & -.337 & .109 & -.250 & -3.081 & .002 \\
\hline
\end{tabular}

Hasil Output SPSS,2020

Pengujian statistik secara parsial ialah :

1. Good Corporate Governance memiliki hasil signifikansi 0,791>0,05 dan hasil $\mathrm{T}_{\text {hitung }}$ diatas $\mathrm{T}_{\text {tabel }}(0,266<1,65494) \mathrm{H}_{0}$ diterima dan $\mathrm{H}_{\mathrm{a}}$ ditolak yang berarti bahwa variabel Good Corporate Governance secara parsial tidak berpengaruh dan tidak signifikan terhadap Return on investment pada perusahaan Aneka Idustri, Industri Dasar dan Kimia yang Terdaftar di Bursa Efek Indonesia pada Tahun 2014-2017.

2. Frim Size memiliki hasil signifikan $0,797>0,05$ dan nilai $\mathrm{T}_{\text {hitung }}$ lebih besar dari $\mathrm{T}_{\text {tabel }}(-0,257<1,65494)$ maka $\mathrm{H}_{0}$ ditolak dan $\mathrm{H}_{\mathrm{a}}$ diterima maksutnya bahwa variabel Frim Size secara parsial berpengaruh negatif dan tidak signifikan terhadap ROI pada perusahaan tersebut.

3. Variabel Struktur modal mempunyai hasil signifikan $0,002<0,005$ dan nilai $\mathrm{T}_{\text {hitung }}<\mathrm{T}_{\text {tabel }}(-3,081<1,65494)$ maka $\mathrm{H}_{0}$ diterima dan $\mathrm{H}_{\mathrm{a}}$ ditolak maksut dari variabel Struktur Modal secara parsial berpengaruh negatif dan signifikan terhadap Return on investmet pada perusahaan tersebut.

\section{Pembahasan}

Pengaruh Good Corporate Governance (GCG) terhadap Pengembalian Investasi 
Hasil analisis menyatakan bahwa Good Corporate Governance (GCG) secara parsial tidak memiliki pengaruh positif dan signifikan terhadap Pengembalian Investasi di berbagai perusahaan industri, dasar dan kimia yang terdaftar di Bursa Efek Indonesia di berbagai perusahaan industri, industri dasar, dan industri kimia pada 2014 - 2017.

Hasil penelitian ini sesuai dengan penelitian yang dilakukan oleh (Wati, 2012) berjudul "pengaruh praktek Good Corporate governance, terhadap Kinerja Keuangan Perusahaan Bursa Efek Indonesia" hasil menunjukkan bahwa tata kelola perusahaan yang baik memiliki pengaruh signifikan terhadap pengembalian investasi. Hasil penelitian ini tidak sesuai dengan penelian yang dilakukan oleh (Adi Sindhu Nurcahya, Endang Dwi Wahyuni, 2014) berjudul “ Pengaruh Good corporate governance, Ukuran perusahaan dan Leverage terhadap Kinerja Keuangan perusahaan" hasil menunjukkan bahwa dewan komisaris independen secara parsial tidak berpengaruh signifikan terhadap kinerja keuangan.

\section{Pengaruh Ukuran Perusahaan terhadap Pengembalian Investasi}

Hasil analisis menyatakan bahwa ukuran perusahaan memiliki pengaruh negatif dan tidak signifikan terhadap pengembalian investasi di berbagai perusahaan industri, dasar, dan kimia yang terdaftar di Bursa Efek Indonesia pada 2014-2017.

Hasil penelitian ini setuju dengan penelitian yang dilakukan oleh (Astri Aprianingsih, 2016) yang berjudul "pengaruh penerapan tata kelola perusahaan yang baik, struktur kepemilikan dan ukuran perusahaan terhadap kinerja keuangan perusahaan perbankan "Hasil menunjukkan bahwa ukuran perusahaan berpengaruh positif terhadap kinerja keuangan perbankan yang terdaftar diperusahaan BEI 2011-2014. Hasil penelitian kami tidak sesuai dengan penelitian yang dilakukan oleh
(Epi, 2017) yang berjudul "Pengaruh Ukuran Perusahaan, Struktur Kepemilikan Manajerial, dan Manajemen Laba Terhadap Kinerja Perusahaan Property dan Realestate yang terdaftar pada Bursa Efek Indonesia" hasil menunjukkan bahwa ukuran perusahaan tidak mempunyai pengruh terhadap kinerja perusahaan.

\section{Pengaruh Struktur Modal terhadap Pengembalian Investasi}

Hasil analisis menyatakan bahwa struktur modal memiliki pengaruh negatif dan signifikan terhadap pengembalian investasi di berbagai perusahaan industri, industri dasar, dan bahan kimia pada 2014-2017.

Hasil penelitian ini sesuai dengan penelitian yang dilakukan oleh (Abdul Azis, Dr.Ulil Hartono, S.E., 2017) yang berjudul Pengaruh Good Corporate Governance, Struktur modal, dan Leverance, Terhadap kinerja keuangan perusahaan sektor pertambangan yang terdaftar di bursa efek indonesia Tahun 20112015 "hasil menunjukkan bahwa DER berpengaruh terhadap kinerja keuangan perusahaan. Hasil penelitian ini tidak sesuai dengan penelitian yang dilakukan oleh (Anggriaini, 2017) yang berjudul “ Pengaruh Struktur Modal Terhadap Kinerja Keuangan pada perusahaan Farmasi yang terdaftar di Bursa Efek Indonesia Periode 2010-2014" hasil menunjukkan bahwa DER secara parsial tidak ada pengaruh yang signifikan terhadap ROA.

\section{KESIMPULAN DAN SARAN}

Berdasarkan analisis dan pembahasan dapat disimpulkan bahwa Variabel Independen Good Corporate Governance secara parsial tidak berpengaruh dan tidak signifikan terhadap kinerja keuangan. Variabel Ukuran Perusahaan secara parsial memiliki pengaruh negatif dan tidak signifikan terhadap kinerja keuangan dalam penelitian ini. Variabel struktur modal secara parsial berpengaruh negatif dan signifikan terhadap kinerja keuangan. 
Berdasarkan hasil analisis dan kesimpulan yang telah dijelaskan, penulis memberikan beberapa saran terkait dengan penelitian yang telah dilakukan. Untuk perusahaan: berdasarkan penelitian yang telah diperoleh terkait dengan pengaruh langkah-langkah tata kelola perusahaan yang baik dan struktur modal terhadap kinerja keuangan di berbagai perusahaan industri, dasar, dan kimia pada 20142017. Peneliti berharap emiten akan meningkat sehingga volume penjualan akan meningkat untuk mengimbangi total aset yang dimiliki dan lebih memaksimalkan peran saham sebagai sumber modal sehingga menghasilkan kinerja keuangan yang baik. Untuk peneliti masa depan: disarankan sebagai referensi dan pertimbangan informasi untuk penelitian masa depan dengan variabel yang berbeda dan penting untuk meninjau kembali dengan mengalikan variabel yang mungkin lainnya dengan mempengaruhi kinerja keuangan (ROI).

\section{Saran}

Berlandaskan kesimpulan dapat diuraikan diatas, maka disarankan:

1. Perusahaan

Berdasarkan penelitian yang telah dilaksanakan terkait pengaruh GCG, firm size dan struktur modal terhadap ROI pada perusahaan aneka industri,industri dasar dan kimia pada tahun 2014- 2017. Peneliti berharap agar emiten meningkat cara untuk volume penjualan naik agar mengimbangi total aset yang dimiliki dan lebih maksimal peran saham sebagai sumber permodalaan sehingga mendapatkan kinerja keuangan yang baik pula.

2. Peneliti selanjutnya

Disarankan bagai bahan refrensi dan pertimbangan informasi untuk penelitian selepas itu dengan variabel yang berbeda dan harus dilaksanakan penelitian ulang dengan menambah variabel-variabel lain yang mungkin mempengaruhi kinerja keuangan (ROI).

\section{DAFTAR PUSTAKA}

Abdul Azis, Dr.Ulil Hartono, S.E., M. S. (2017). Pengaruh Good corporate governance, Struktur modal, dan Leverance terhadap Kinerja Keuangan Perusahaan Pada Sektor Pertambangan Yang Terdaftar Di Bursa Efek Indonesia Tahun 20112015. Jurnal Ilmu Manajemen, Fakultas Ekonomi, Universitas Negeri Surabaya.

Adi Sindhu Nurcahya, Endang Dwi Wahyuni, S. S. (2014). Pengaruh Good corporate governance,Ukuran perusahaan, Leverage Terhadap Kinerja keuangan Perusahaan. Universitas Muhammadiah Malang.

Anggriaini, N. (2017). Pengaruh Struktur Modal Terhadap Kinerja Keuangan Pada Keuangan Farmasi yang Terdaftar di Bursa Efek Indonesia periode 20102014. Universitas Riau.

Astri Aprianingsih, A. N. Y. (2016). Pengaruh Penerapan Good corporate governance, Struktur kepemilikan,dan Ukuran perusahaan terhadap Kinerja Keuangan Perbankan. Universitas Negeri Yogyakarta.

Epi, Y. (2017). Pengaruh Ukuran Perusahaan, Struktur Kepemilikan Manajerial,dan Manajemen Laba terhadap Kinerja Perusahaan Property dan Realestate yang terdaftar di Bursa Efek Indonesia. 1(1).

Fahmi, I. (2015). Manajemen Perbankan Konevensional dan Syariah. Mitra Wacana Media.

Jumingan. (2014). Analisis Laporan Keuangan. PT Bumi Aksara.

Nugraha, A. A. (2013). Analisis pengaruh Struktur Modal Terhadap Kinerja Perusahaan yang Tergabung dalam indeks Kompas 100. Universitas Negeri semarang.

Panky Pradana Sukandar, R. (2014). Pengaruh Ukuran Dewan Direksi dan Dewan Komisaris Serta Ukuran Perusahaan Terhadap Kinerja Keuangan Perusahaan. Jurnal Jurusan Akuntansi Fakultas Ekonomi Dan Bisnis Universitas Diponegoro.

Rodoni, Ahmad dan Ali, H. (2010). Menejemen Keuangan. Binarupa Aksara.

Sartono, A. (2010). Manajemen Keuangan Teori dan Aplikasi (4th ed.). BPFE. 
Sembiring, S. (2008). Pengaruh Ukuran Perusahaan Dan Kebijakan pendanaan Terhadap Kinerja Keuangan Pada Perusahaan Bisnis Properti Di Bursa Efek Indonesia Jakarta. In Skripsi Sekolah Paska Sarjana. Universitas Sumatera Utara.

Sugiyono. (2016). Metode Penelitian Kuantitatif, Kualitatif, dan R\&D. PT ALFABETA.

Veno, A. (2015). Pengaruh Good Corporate Governance Terhadap Kinerja Perusahaan Pada Perusahaan
Manufaktur Go public ( Studi empiris pada perusahaan yang terdaftar di BEI 2011 sampai 2013). Junal Manajemen Dan Bisnis Universitas Muhammadiyah Surakarta.

Wati, L. M. (2012). Pengaruh Praktek Good Corporate Governance, Terhadap Kinerja Keuangan Perusahaan Di Bursa Efek Indonesia. Jurnal Manajemen, Program Studi Manajemen Fakultas Ekonomi. 